\title{
Homelessness in France: Labour-market implications
}

This paper analyses homelessness in France with regard to three major mutually interacting sets of factors: labour-market strains, illegal migration and institutional inadequacy. Macroeconomic challenges have resulted in the loss of jobs and subsequent labour-market hardships, and these have tended to affect those without adequate skills. As a result, labour-market problems together with a lack of social capital and adequate housing at affordable prices, accompanied by insufficient institutional support, has resulted in increased homelessness. All of this indicates that there should be active government intervention in the housing market in order to create space for the relatively weaker section of the population in the growth process, which is often unequal. Another important issue is how to create jobs with positive growth in real wages because, without adequate purchasing power, simply providing housing would mean transferring poverty from one space to another.

Keywords: homeless, jobless, labour market, housing market, France 


\section{Introduction}

Homelessness is an important indicator of poverty, although there are poor households that have access to housing. Nonetheless, the social profile of both the homeless and the poor that have housing can be quite similar (see Marpsat, 2000). Access to food, particularly in developed countries, may not be difficult with the increased roles of government, the local authorities and many civil society organisations working for those that are unable to work. However, housing may not be affordable even for those that are employed, although joblessness tends to substantially reduce individuals' access to housing. Increased globalisation raises the question of how the labour-market situation has changed in developed countries like France and whether it has increased the vulnerability to homelessness of certain segments of the workforce. The standard Heckscher-Ohlin theorem suggests that developed countries may specialise in the production of capital-intensive goods whereas developing countries may pursue labour-intensive production. Trade between countries is expected to generate demand for labour in developing countries and income inequality may therefore decline. However, in reality wage inequality in developing countries has risen because trade-induced growth has been accompanied by a rise in skill levels, and the premium to skill is substantial. On the other hand, relatively less skilled persons in the developed world - although they can be considered skilled in terms of the prevailing standards in developing countries - are believed to have lost jobs because many of their jobs have been shifted to developing countries through outsourcing and the increase in business-process outsourcing services. Hence, with globalisation the developed countries are also likely to have experienced a rise in inequality and therefore those at the bottom of the skill ladder may have suffered from job loss and income loss, which also affects their access to housing. Particularly in large cities with inadequate space for further expansion, the housing market has seen skyrocketing prices, which appears to have made those in irregular jobs more prone to homelessness.

In identifying the cause of homelessness, something more endemic and more intrinsic needs to be discussed. However, this does not deny that some homeless people could be seriously ill and, in facts, illness reduces the probability of joining the labour market. Maryse Marpsat (2009) noted that some former homeless persons that now have accommodation of their own still use hot-meal distribution services, implying that they are poor and that their poverty could be attributed to a physical or mental disability. Construction workers that have suffered work-related injuries fall into this category. When they receive official recognition of their disability, this gives them access to certain support services, which prevents them from becoming homeless, although the inability to work forces them to be poor. However, the fact is that there are people that are homeless and nonetheless not mentally deranged from the point of view of the rest of the society, and this is an important challenge to the view that mental disorders and homelessness are connected.

The working hypotheses can be summarised as follows:

- Employees from households with a weak social support system and poor human capital formation are less equipped, particularly at a later stage of their job career (after fifty), to face the labour-market challenges posed by economic recessions and globalisation.

- Even among younger entrants to the labour market, the job-market situation is quite difficult if they happen to have less skill and education. In particular, children from broken homes do not have high levels of skill, which in turn tends to affect their job-market status.

- It is more difficult for immigrants from eastern Europe and other relatively low-income areas to get regular jobs, which in turn reduces their access to housing (the lack of address corresponds to the lack of a job, and vice versa).

- With the enormous rise in housing prices, workers in relatively low-income jobs are finding it impossible to access housing even when they have generally been working regularly.

- Inadequate safety nets for certain groups make them more prone to homelessness. ${ }^{[1]}$

This study is organised as follows. Section 2 deals with the labour-market characteristics of the French economy. The issues relating to the homeless population in France in general and in Paris in particular are discussed in section 3. Finally, section 4 summarises the major findings.

\section{Labour-market analysis}

The labour-force participation rate (LFPR), defined as the proportion of those in the labour market to total population (age 15 and above), follows a U-shaped relationship across countries located at various levels of development and per capita income. However, in a given country, unless the data set covers a very long time span (e.g., several decades) the LFPR is expected to remain stable because it is a function of several variables that operate simultaneously in the same and opposite directions. The French economy witnessed a substantial decline in the participation rate from around 59\% during the 1980 s to $52 \%$ during the 1990s. Although there was a marginal increase after that, particularly around 2004 and 2005, the rate again fell to $52 \%$ in 2008 . Because the LFPR is a function of both demand- and supply-side variables, the decline needs to be judged carefully. From the supply point of view, workers (particularly women) may withdraw from the labour market if incomes are 
Table 1: LFPR in France (\%).

\begin{tabular}{llll}
\hline Year & LFPR & Year & LFPR \\
\hline 1980 & 57.1 & 1995 & 51.7 \\
\hline 1981 & 56.8 & 1996 & 52.1 \\
\hline 1982 & 56.7 & 1997 & 51.8 \\
\hline 1983 & 56.3 & 1998 & 52.0 \\
\hline 1984 & 56.0 & 1999 & 52.2 \\
\hline 1985 & 56.0 & 2000 & 52.3 \\
\hline 1986 & 56.0 & 2001 & 52.3 \\
\hline 1987 & 55.7 & 2002 & 52.4 \\
\hline 1988 & 55.2 & 2003 & 53.1 \\
\hline 1989 & 55.1 & 2004 & 52.9 \\
\hline 1990 & 52.2 & 2005 & 52.6 \\
\hline 1991 & 51.8 & 2006 & 52.4 \\
\hline 1992 & 51.8 & 2007 & 52.3 \\
\hline 1993 & 51.7 & 2008 & 52.0 \\
\hline 1994 & 51.6 & & \\
\hline
\end{tabular}

Note: Population age 15 and above is included and both sexes are combined.

Source: International Labour Organisation (ILO, 2009).

increasing faster so that some of the members within a household can afford to be outside the labour market and invest their time on aspects that also contribute to enhancing the wellbeing of the household. On the other hand, a depressed labour-market situation can also lead to withdrawal from the labour market (the phenomenon of discouraged dropouts). In the context of the French economy, the latter seems to be the more likely possibility for reasons mentioned below.

Table 2 shows that the percentage of the labour force with a tertiary education increased sharply among both sexes, but the share of the labour force with only a primary education declined from 1996 to 2007. In addition, there was a decline in the share of female labour force with a secondary education. With a rise in the level of education, it is expected that

Table 2: Labour force by education in France (\%).

\begin{tabular}{lllllll}
\hline \multirow{2}{*}{ Year } & \multicolumn{5}{c}{ Female } & \multicolumn{5}{l}{ Male } \\
\cline { 2 - 7 } & Primary & Secondary & Tertiary & Primary & Secondary & Tertiary \\
\hline 1996 & 29.6 & 46.2 & 24.3 & 38.4 & 41.1 & 20.4 \\
\hline 1997 & 28.0 & 46.5 & 25.5 & 36.9 & 41.9 & 21.3 \\
\hline 1998 & 26.6 & 47.2 & 26.2 & 35.7 & 42.7 & 21.7 \\
\hline 2000 & 24.0 & 47.8 & 28.3 & 32.4 & 44.6 & 23.0 \\
\hline 2001 & 22.9 & 48.0 & 29.2 & 30.1 & 46.0 & 23.9 \\
\hline 2005 & 28.0 & 41.7 & 29.8 & 28.2 & 46.6 & 24.6 \\
\hline 2006 & 26.8 & 41.3 & 31.5 & 27.3 & 46.2 & 26.1 \\
\hline 2007 & 25.5 & 41.9 & 32.3 & 26.5 & 46.4 & 26.8 \\
\hline
\end{tabular}

Note: Population age 15 and above is included.

Source: ILO (2009).
Table 3: Work participation rate in France.

\begin{tabular}{|c|c|c|c|c|}
\hline Year & $\begin{array}{l}\text { Employ- } \\
\text { ment-to-popula- } \\
\text { tion ratio } \\
\text { (\% among } \\
\text { female) }\end{array}$ & $\begin{array}{l}\text { Employ- } \\
\text { ment-to-popu- } \\
\text { lation ratio } \\
\text { (\% among } \\
\text { male) }\end{array}$ & $\begin{array}{l}\text { Females per } \\
1,000 \text { males, } \\
\text { population }\end{array}$ & $\begin{array}{l}\text { Females per } \\
1,000 \text { males, } \\
\text { employees }\end{array}$ \\
\hline 1980 & 40.4 & 67.8 & $1,079.7$ & 642.8 \\
\hline 1981 & 40.2 & 66.4 & $1,080.3$ & 653.6 \\
\hline 1982 & 40.2 & 65.4 & $1,081.6$ & 664.3 \\
\hline 1983 & 40.1 & 64.3 & $1,080.4$ & 673.9 \\
\hline 1984 & 39.8 & 62.6 & $1,081.0$ & 686.8 \\
\hline 1985 & 39.6 & 61.7 & $1,081.2$ & 693.9 \\
\hline 1986 & 40.2 & 61.2 & $1,081.3$ & 710.3 \\
\hline 1987 & 39.6 & 60.5 & $1,082.3$ & 708.0 \\
\hline 1988 & 39.8 & 60.1 & $1,082.1$ & 715.9 \\
\hline 1989 & 40.1 & 60.4 & $1,081.7$ & 718.2 \\
\hline 1990 & 40.4 & 59.8 & $1,080.5$ & 728.7 \\
\hline 1991 & 40.7 & 59.3 & $1,081.8$ & 742.0 \\
\hline 1992 & 40.5 & 58.6 & $1,081.2$ & 747.7 \\
\hline 1993 & 40.7 & 57.2 & $1,081.5$ & 769.5 \\
\hline 1994 & 40.3 & 55.9 & $1,082.0$ & 779.0 \\
\hline 1995 & 40.7 & 56.3 & $1,082.5$ & 783.3 \\
\hline 1996 & 40.8 & 56.2 & $1,082.6$ & 787.2 \\
\hline 1997 & 40.6 & 55.6 & $1,083.3$ & 790.9 \\
\hline 1998 & 41.1 & 55.7 & $1,083.4$ & 798.8 \\
\hline 1999 & 41.4 & 55.6 & $1,084.0$ & 806.5 \\
\hline 2000 & 42.4 & 56.7 & $1,083.3$ & 811.1 \\
\hline 2001 & 43.1 & 57.4 & $1,082.6$ & 812.9 \\
\hline 2002 & 43.5 & 57.0 & $1,082.0$ & 827.1 \\
\hline 2003 & 45.3 & 57.8 & $1,083.2$ & 849.5 \\
\hline 2004 & 45.4 & 57.4 & $1,082.7$ & 855.1 \\
\hline 2005 & 45.6 & 57.3 & $1,082.2$ & 862.4 \\
\hline 2006 & 45.8 & 57.0 & $1,081.6$ & 869.3 \\
\hline 2007 & 46.8 & 57.3 & $1,081.0$ & 882.6 \\
\hline 2008 & 47.3 & 58.0 & $1,080.3$ & 886.3 \\
\hline
\end{tabular}

Source: ILO (2009).

potential entrants do not wish to join the labour market unless jobs of desirable quality are available. However, before drawing any conclusions in this regard, it is necessary to look at the work participation rate as well.

Among males there has been a sharp and steady decline in the employment-to-population ratio since the 1980s (Table 3). The decline started in the early 1980s and the trend continued during the 1990s (almost to 1998/99), although after this it improved marginally and it seems to have stabilised at around 57\%. Among females, however, the rate generally remained constant over the 1980s and the 1990s (with a few exceptions when it dipped), and since 1999 there has been a steady rise. This pattern is also reflected in the gender ratio: although the 
gender ratio of the total population remained more or less constant from 1980 to 2008, there has been a steady increase in the gender ratio of the workforce.

On the whole, among males the depressing effect of the labour market is quite prominent. Even in absolute terms, the number of those fully employed declined from 1983 to 1999 among males (Table 4). The deterioration in the labour-market conditions with a lack of jobs may have led to a withdrawal from the labour market, resulting in a decline in both the LFPR and the work participation rate among males. In fact, as Pietro Garibaldi and Etienne Wasmer (2002) point out, the number of workers that quit the labour market on losing their jobs (from employment to inactivity) is greater than the number of workers that join the unemployment pool. Hence, the decline in the work participation rate is in response to the job market tightening. The rise in part-time employment among males even in absolute terms and as a percentage of total male employment, as seen from Table 4, could cause job-market conditions to deteriorate even further. In addition, the unemployment rate also increased steadily among males until 1999 (Table 5). Long-term unemployment, youth unemployment and low labour-market participation of able workers motivated the authorities to create new state-subsidised employment in 1997 through the program New Services for Youth Employment (Fr. Nouveaux services pour l'emploi des jeunes, for people under 30), in addition to the earlier state-subsidised Solidarity Employment Contract (Fr. Contrat d'Emploi Solidarity, CES) and Consolidated Employment Contract (Fr. Contrat Emploi Consolidé, CEC) plans, created in 1989 and 1992. At the end of the 1990s, two important laws were passed: the first was the Law against Social Exclusion (Fr. Loi de Prévention et

Table 4: Fulltime and part-time employment in France.

\begin{tabular}{|c|c|c|c|c|c|c|}
\hline \multirow[t]{2}{*}{ Year } & \multicolumn{3}{|l|}{ Female } & \multicolumn{3}{|l|}{ Male } \\
\hline & $\begin{array}{l}\text { Part-time } \\
\text { workers ('000) }\end{array}$ & $\begin{array}{l}\text { Part-time } \\
\text { employment } \\
\text { rate (\%) }\end{array}$ & $\begin{array}{l}\text { Fulltime } \\
\text { employment } \\
(' 000)\end{array}$ & $\begin{array}{l}\text { Part-time } \\
\text { workers } \\
(' 000)\end{array}$ & $\begin{array}{l}\text { Part-time } \\
\text { employment } \\
\text { rate (\%) }\end{array}$ & $\begin{array}{l}\text { Fulltime } \\
\text { employment } \\
\text { ('000) }\end{array}$ \\
\hline 1983 & $1,741.6$ & 20.3 & $6,853.8$ & 430.3 & 3.4 & $12,053.3$ \\
\hline 1984 & $1,862.4$ & 21.4 & $6,821.6$ & 501.7 & 4.1 & $11,830.8$ \\
\hline 1985 & $1,892.9$ & 21.6 & $6,854.9$ & 555.7 & 4.5 & $11,703.9$ \\
\hline 1986 & $2,050.6$ & 23.0 & $6,881.0$ & 620.8 & 5.1 & $11,629.7$ \\
\hline 1987 & $2,019.5$ & 22.8 & $6,840.2$ & 622.9 & 5.1 & $11,582.7$ \\
\hline 1988 & $2,056.8$ & 23.0 & $6,897.2$ & 598.4 & 4.9 & $11,583.8$ \\
\hline 1989 & $2,034.2$ & 22.1 & $7,164.3$ & 605.8 & 4.8 & $11,927.1$ \\
\hline 1990 & $2,079.7$ & 22.5 & $7,150.3$ & 565.2 & 4.5 & $11,938.4$ \\
\hline 1991 & $2,025.0$ & 21.8 & $7,241.0$ & 544.4 & 4.5 & $11,532.8$ \\
\hline 1992 & $2,131.2$ & 22.7 & $7,248.9$ & 573.7 & 4.7 & $11,599.1$ \\
\hline 1993 & $2,262.0$ & 23.7 & $7,299.2$ & 600.3 & 4.9 & $11,537.5$ \\
\hline 1994 & $2,341.7$ & 24.5 & $7,219.0$ & 635.8 & 5.3 & $11,382.3$ \\
\hline 1995 & $2,416.5$ & 24.8 & $7,312.7$ & 683.8 & 5.6 & $11,492.7$ \\
\hline 1996 & $2,392.7$ & 24.4 & $7,417.3$ & 700.2 & 5.7 & $11,511.5$ \\
\hline 1997 & $2,526.8$ & 25.8 & $7,265.3$ & 715.2 & 5.9 & $11,449.3$ \\
\hline 1998 & $2,543.5$ & 25.5 & $7,419.8$ & 723.4 & 5.9 & $11,560.0$ \\
\hline 1999 & $2,561.7$ & 25.4 & $7,538.2$ & 715.3 & 5.8 & $11,692.9$ \\
\hline 2000 & $2,588.9$ & 24.9 & $7,808.3$ & 695.8 & 5.5 & $12,029.8$ \\
\hline 2001 & $2,599.7$ & 24.4 & $8,035.4$ & 667.9 & 5.1 & $12,374.7$ \\
\hline 2002 & $2,340.8$ & 23.6 & $7,562.4$ & 565.5 & 5.1 & $10,542.4$ \\
\hline 2003 & $2,504.2$ & 22.7 & $8,543.4$ & 605.4 & 4.7 & $12,376.6$ \\
\hline 2004 & $2,600.6$ & 23.4 & $8,508.5$ & 622.5 & 4.7 & $12,513.7$ \\
\hline 2005 & $2,603.0$ & 23.0 & $8,711.2$ & 681.8 & 5.2 & $12,426.7$ \\
\hline 2006 & $2,563.1$ & 22.6 & $8,798.1$ & 691.1 & 5.2 & $12,472.9$ \\
\hline 2007 & $2,681.9$ & 23.1 & $8,932.3$ & 655.9 & 4.9 & $12,591.6$ \\
\hline 2008 & $2,708.5$ & 22.7 & $9,242.4$ & 697.1 & 5.2 & $12,794.9$ \\
\hline
\end{tabular}

Note: The part-time employment rate is defined as the proportion of part-time workers to total employment (fulltime and part-time combined). Source: ILO (2009). 
Table 5: Unemployment rate in France.

\begin{tabular}{lllll}
\hline Year & $\begin{array}{l}\text { Unemploy- } \\
\text { ment rate } \\
\text { (\% female) }\end{array}$ & $\begin{array}{l}\text { Unemploy- } \\
\text { ment rate } \\
\text { (\% male) }\end{array}$ & $\begin{array}{l}\text { Females per } \\
1,000 \text { males, } \\
\text { labour force }\end{array}$ & $\begin{array}{l}\text { Females per } \\
1,000 \text { males, } \\
\text { unemployed }\end{array}$ \\
\hline 1980 & 9.1 & 4.1 & 678.1 & $1,505.9$ \\
\hline 1981 & 10.0 & 5.0 & 689.8 & $1,374.7$ \\
\hline 1982 & 10.5 & 5.8 & 699.5 & $1,270.4$ \\
\hline 1983 & 10.5 & 6.1 & 720.6 & $1,238.3$ \\
\hline 1984 & 12.1 & 7.6 & 739.2 & $1,170.2$ \\
\hline 1985 & 12.6 & 8.5 & 745.9 & $1,109.5$ \\
\hline 1986 & 12.3 & 8.7 & 759.4 & $1,072.7$ \\
\hline 1987 & 13.5 & 8.6 & 764.7 & $1,190.9$ \\
\hline 1988 & 12.8 & 8.2 & 771.9 & $1,208.2$ \\
\hline 1989 & 12.6 & 7.3 & 778.3 & $1,340.7$ \\
\hline 1990 & 12.2 & 7.2 & 780.1 & $1,322.3$ \\
\hline 1991 & 11.6 & 7.2 & 795.4 & $1,289.3$ \\
\hline 1992 & 12.8 & 8.2 & 805.4 & $1,277.1$ \\
\hline 1993 & 13.4 & 9.6 & 819.8 & $1,142.7$ \\
\hline 1994 & 14.5 & 11.0 & 827.7 & $1,087.3$ \\
\hline 1995 & 14.0 & 10.0 & 836.9 & $1,178.7$ \\
\hline 1996 & 14.5 & 10.6 & 840.0 & $1,149.2$ \\
\hline 1997 & 14.4 & 11.0 & 837.0 & $1,095.8$ \\
\hline 1998 & 14.1 & 10.3 & 846.6 & $1,153.4$ \\
\hline 1999 & 13.9 & 10.3 & 847.6 & $1,137.9$ \\
\hline 2000 & 12.2 & 8.5 & 851.0 & $1,215.9$ \\
\hline 2001 & 10.5 & 7.0 & 847.4 & $1,272.4$ \\
\hline 2002 & 9.8 & 7.8 & 847.0 & $1,067.9$ \\
\hline 2003 & 9.5 & 7.7 & 872.7 & $1,081.5$ \\
\hline 2004 & 10.4 & 8.2 & 869.3 & $1,102.0$ \\
\hline 2005 & 9.6 & 8.0 & 879.5 & $1,075.6$ \\
\hline 2006 & 9.6 & 8.2 & 884.4 & $1,055.3$ \\
\hline 2007 & 8.5 & 7.4 & 893.4 & $1,024.9$ \\
\hline 2008 & 7.9 & 6.9 & 896.0 & $1,021.1$ \\
\hline
\end{tabular}

Source: ILO (2009).

de lutte contre les exclusions, 1998), which instituted new programmes to facilitate youth employment (16-25 years old). The resulting French Youth Employment Programme (Fr. Trajet d'Accés a l'Emploi, TRACE) facilitated inclusion in the labour market through support and training measures and extended assistance funds to young people (1992). The second law created the Universal Health Insurance (Fr. Cowverture Maladie Universelle, CMU) system in 1999 (see Firdion \& Marpsat, 2007).

Job-market hardships are also reflected in terms of many other indicators. A sizeable percentage of the workforce, particularly among males, was self-employed. Not only has the rate of self-employment been higher among males, but the decline in the self-employment rate has also been much slower among males compared to females over the years (Table 6). The elas-
Table 6: Employment status in France (\%).

\begin{tabular}{|c|c|c|c|c|}
\hline \multirow[t]{2}{*}{ Year } & \multicolumn{2}{|l|}{ Female } & \multicolumn{2}{|l|}{ Male } \\
\hline & $\begin{array}{l}\text { Wage \& sala- } \\
\text { ried workers }\end{array}$ & $\begin{array}{l}\text { Total self-em- } \\
\text { ployed workers }\end{array}$ & $\begin{array}{l}\text { Wage \& salaried } \\
\text { workers }\end{array}$ & $\begin{array}{l}\text { Total self-em- } \\
\text { ployed workers }\end{array}$ \\
\hline 1980 & 85.4 & 14.6 & 82.6 & 17.3 \\
\hline 1981 & 85.5 & 14.5 & 82.8 & 17.1 \\
\hline 1982 & 85.7 & 14.3 & 83.3 & 16.7 \\
\hline 1983 & 86.0 & 14.0 & 83.4 & 16.6 \\
\hline 1984 & 86.4 & 13.6 & 83.4 & 16.5 \\
\hline 1985 & 86.8 & 13.2 & 83.7 & 16.3 \\
\hline 1986 & 87.2 & 12.8 & 83.8 & 16.2 \\
\hline 1987 & 87.5 & 12.5 & 84.0 & 16.0 \\
\hline 1988 & 87.8 & 12.2 & 84.3 & 15.7 \\
\hline 1989 & 88.4 & 11.6 & 84.7 & 15.3 \\
\hline 1990 & 89.0 & 11.0 & 85.1 & 14.8 \\
\hline 1991 & 87.5 & 7.5 & 82.6 & 16.5 \\
\hline 1992 & 87.8 & 7.3 & 82.7 & 16.6 \\
\hline 1993 & 88.8 & 6.8 & 83.5 & 15.7 \\
\hline 1994 & 89.0 & 6.8 & 83.4 & 15.8 \\
\hline 1995 & 89.2 & 7.0 & 84.0 & 15.3 \\
\hline 1996 & 90.0 & 6.6 & 84.2 & 15.1 \\
\hline 1997 & 90.2 & 6.5 & 84.5 & 15.0 \\
\hline 1998 & 90.8 & 6.3 & 84.9 & 14.7 \\
\hline 1999 & 91.1 & 6.1 & 85.2 & 14.4 \\
\hline 2000 & 91.7 & 6.0 & 86.0 & 13.6 \\
\hline 2001 & 92.1 & 5.9 & 86.2 & 13.0 \\
\hline 2002 & 92.3 & 5.7 & 86.7 & 12.9 \\
\hline 2003 & 91.9 & 6.2 & 85.6 & 13.8 \\
\hline 2004 & 92.2 & 5.8 & 86.3 & 13.1 \\
\hline 2005 & 92.5 & 5.9 & 86.2 & 13.3 \\
\hline 2006 & 92.3 & 6.2 & 85.7 & 13.8 \\
\hline 2007 & 92.7 & 6.3 & 86.0 & 13.6 \\
\hline 2008 & 92.7 & 6.4 & 86.7 & 13.0 \\
\hline
\end{tabular}

Source: ILO (2009).

ticity of male employment was in fact negative in the first half of the 1990s, and then improved to less than one-fourth between 1996 and 2000. The annual number of hours actually worked per person has also shown a steady decline over the years (1980-2008; see Figure 1).

Towards the second half of the 1990s, an economic expansion in France seems to have taken place, resulting in job expansion and a reduction in unemployment despite a sluggish growth rate in output (Estevao \& Nargis, 2005). Jean Pisani-Ferry (2000) and Jörg Decressin et al. (2001) characterised this upswing as "rich in employment". Three basic reasons can be proposed to explain this phenomenon: a) the basic parameters of the wage-setting mechanism changed to result in a rightward shift in the labour supply function in the employment-wage constellation (Decressin et al., 2001), b) a reduction in firms' 


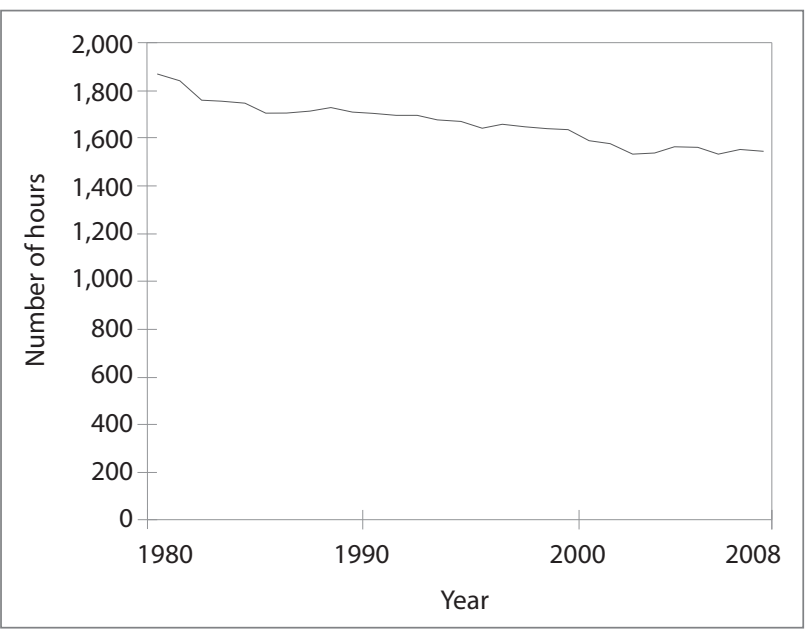

Figure 1: Annual number of hours actually worked per person in France (source: ILO, 2009).

social security contributions led to a subsequent rise in labour demand (Crepon \& Desplatz, 2001) and c) a structural improvement in labour-market functioning implied not only a large share of job growth accompanied by sluggish wages, but also an increase in investment. However, the fact that a large part of the increase in jobs has been accompanied by sluggish growth in wages implies increasing hardships in overall wellbeing. Although labour productivity for the aggregate economy (defined as the GDP per person engaged) increased steadily throughout (1980-2008), male wages in the manufacturing sector were largely stagnant throughout the 1990s (Table 7). Given the high cost of housing, an increase in employment with low wages does not tend to result in any major improvement in terms of access to housing.

The other factor that led to labour-market tightening during the 1980s and 1990s is the inflexibility of Vocational Education and Training (VET) institutes, as Frans Meijers (1998) argued. Many European countries have now transformed into post-industrial societies with rapid economic and social change. In such societies it is not knowledge as such but competencies that have become the pivot on which everything turns, as he argues. In an industrial society in which socioeconomic and political relations are stable, the vocational education and training system does not have to change in a qualitative way but only has to adapt quantitatively to the changing demand for skilled employees. However, in a post-industrial situation a management system that is organised top-down does not work efficiently because it is too rigid and creates an enormous distance between the schools and the labour market. Unless the VET system changes to suit the changes that have already taken place on the economic, social and political fronts and bridges the gap between the actual labour market and the VET system, the labour-market hardships will continue to be reflected in many ways, as the same author argues. In fact, an unprecedented rise in the unemployment rate is also an
Table 7: Productivity and manufacturing real wage indices in France.

\begin{tabular}{lllll}
\hline Year & $\begin{array}{l}\text { Real manu- } \\
\text { facturing } \\
\text { wage } \\
\text { (Female) }\end{array}$ & $\begin{array}{l}\text { Real manufac- } \\
\text { turing wage } \\
\text { (Male) }\end{array}$ & $\begin{array}{l}\text { GDP per person } \\
\text { engaged (con- } \\
\text { stant 1990 } \\
\text { USD at PPP) }\end{array}$ & $\begin{array}{l}\text { GDP per per- } \\
\text { son engaged } \\
(1990=100)\end{array}$ \\
\hline 1980 & 87.0 & 89.8 & $36,652.7$ & 81.6 \\
\hline 1981 & 89.4 & 90.9 & $37,171.2$ & 82.8 \\
\hline 1982 & 90.4 & 92.4 & $38,059.4$ & 84.8 \\
\hline 1983 & 93.7 & 94.8 & $38,623.1$ & 86.0 \\
\hline 1984 & 92.7 & 94.0 & $39,437.1$ & 87.8 \\
\hline 1985 & 93.2 & 93.6 & $40,138.4$ & 89.4 \\
\hline 1986 & 94.3 & 94.3 & $40,939.4$ & 91.2 \\
\hline 1987 & 95.2 & 95.5 & $41,656.7$ & 92.8 \\
\hline 1988 & 94.8 & 95.1 & $43,093.5$ & 96.0 \\
\hline 1989 & 94.5 & 95.6 & $44,100.4$ & 98.2 \\
\hline 1990 & 96.1 & 96.8 & $44,897.5$ & 100.0 \\
\hline 1991 & 96.9 & 97.8 & $45,303.9$ & 100.9 \\
\hline 1992 & 98.2 & 99.2 & $46,191.4$ & 102.9 \\
\hline 1993 & 99.1 & 99.5 & $46,366.4$ & 103.3 \\
\hline 1994 & 99.4 & 100.0 & $47,326.2$ & 105.4 \\
\hline 1995 & 100.0 & 100.0 & $47,902.2$ & 106.7 \\
\hline 1996 & 90.9 & 93.8 & $48,253.3$ & 107.5 \\
\hline 1997 & 92.4 & 94.0 & $49,117.4$ & 109.4 \\
\hline 1998 & 94.4 & 95.4 & $50,076.4$ & 111.5 \\
\hline 1999 & 96.5 & 96.9 & $50,703.3$ & 112.9 \\
\hline 2000 & 100.0 & 100.0 & $51,311.0$ & 114.3 \\
\hline 2001 & 103.4 & 102.3 & $51,348.7$ & 114.4 \\
\hline 2002 & 106.3 & 104.2 & $51,555.2$ & 114.8 \\
\hline 2003 & 108.2 & 105.9 & $52,051.1$ & 115.9 \\
\hline 2004 & 109.8 & 106.8 & $53,279.2$ & 118.7 \\
\hline 2005 & 111.6 & 107.0 & $53,988.9$ & 120.3 \\
\hline 2006 & & & $54,663.4$ & 121.8 \\
\hline 2007 & & $54,931.4$ & 122.3 \\
\hline 2008 & & $55,052.4$ & 122.6 \\
\hline & & & & \\
\hline
\end{tabular}

Note: $P P P=$ purchasing power parity adjusted. Taking the 1990 figure as 100 , indexation has been carried out for the other years.

Source: ILO (2009).

outcome of this maladjustment of the education system with the changing environment. The possibility of links between rising unemployment and homelessness cannot be ruled out. The next section reviews studies on homelessness in greater detail and examines evidence in favour of this hypothesis.

\section{Results of homeless population surveys}

This section examines the issue of homelessness and its links with the labour-market strains that have appeared since the 1980s. It also assesses the impact of other factors such as the 
lack of social capital, illegal migration from other areas, including eastern Europe, and institutions conceptualised in terms of government and civil society interventions in facilitating the supply of housing to economically weaker sections of the population.

Several definitions of homelessness can be found in European studies. An operational definition as proposed by European Federation of National Organisations working with the Homeless (Fr. Fédération Européenne d'Associations Nationales Travaillant avec les Sans-Abri, FEANTSA) refers to a person that is incapable of obtaining and maintaining an adequate personal dwelling through his or her own means, or incapable of maintaining a dwelling without the aid of social services (Avramov, 1995). This definition is used in many studies funded by European Community agencies. However, the definition involves a certain arbitrariness. As Pierre Philippot et al. (2007) point out, what is an "adequate" personal dwelling and how long one should be incapable of maintaining an adequate dwelling to qualify as homeless are some of the practical ambiguities. Those that directly collect data on homeless samples have used the "literal definition of homelessness", which is derived from the Stuart B. McKinney Homeless Assistance Act of 1987 (see Vazquez et al., 2005; Toro et al., 2007).

There is no official definition of homelessness per se in France. The homeless surveys conducted by the French National Institute for Demographic Studies (Fr. Institut National d'Etudes Démographiques, INED) locally and by the National Institute for Statistics and Economic Studies (Fr. Institut National de la Statistique et des Études Économiques, INSEE) at the national level are based on a definition of homelessness that is close to the U.S. concept of "literal homelessness" (Fr. sans-domicile au sens restreint): the homeless are people that, at the time of the survey (e.g., the night before) are sleeping on the street or in other places unfit for human habitation, and persons living in shelters, hotels or flats paid for by NGOs or public agencies. This definition uses a combination of two classifications: housing type (street, shelters, flats etc.) and occupancy status (paid for by NGOs; Firdion \& Marpsat, 2003).

For operational purposes, the INSEE survey drew samples from those that have been using various support services such as accommodation and hot-meal distribution. The results presented in 2002 for January 2001 showed a figure of just under 100,000 people. However, this could have been grossly underestimated because the French charitable network is minimal compared with the American one and, in addition, the survey excluded difficult housing situations in which people are forced to live with close relations and residents of cramped or unhygienic housing, non-French speakers, homeless people not using accommodation and meal services, and those living in towns with fewer than 20,000 inhabitants. As an article in The New York Times indicated, the dimensions of the housing problem are difficult to measure. Private associations supporting the homeless estimate that half a million people live in inadequate housing in France, whereas government officials put the number of people without a permanent home at about 200,000 (Riding, 1993). As the author reiterates, the phenomenon is growing and, in Paris at least, the sight of homeless people sleeping in doorways no longer causes surprise.

Turning to the causes of homelessness, Jean-Marie Firdion and Marpsat (2007) pointed out that the visibility of homeless people in France increased during the 1980s, when the economic crisis hit, resulting in growing insecurity due to unemployment. Due to the lack of fulltime and permanent jobs (specifically low-skilled jobs) and limitations on unemployment benefits, the resources of single adults or families fell dramatically. At the same time, young adults had difficulty entering the labour market, resulting in a decrease in people's ability to afford housing and remain in the social mainstream. This was when family bonds were also weakening. In addition, the stock of privately owned low-quality and inexpensive housing declined either because of demolition or renovation work, and the original inhabitants were later replaced by wealthier residents. Further, Marpsat and Firdion (1996) and Firdion and Marpsat (2007) noted that separation from the family at an early age has been a dominant characteristic of the users of shelters and soup kitchens in Paris, implying that psychological and social risk factors are important among the homeless population. ${ }^{[2]}$ Often the homeless came from large families (only one-fifth had no brothers or sisters, whereas one-third had five or more).

Personal problems and debts increase the risk of homelessness in childhood and are linked to poverty and low socioeconomic status. Poor physical and mental health as an adult is strongly related to poor living conditions during childhood (e.g., a poor family, being an illegal migrant etc.), and poor health has an impact on employability. Regarding young people (16-24 years old) that are susceptible to homeless-like situations (residing in shelters, daytime care centres and facilities for young people in social distress although they are not completely homeless), Marpsat, Firdion and Monique Meron (2000) noted that migration and institutionalisation play an important role. Among the homeless population, foreign nationals (young adults 18 to 29 years old) account for a significant proportion. The proportion of foreign nationals that are homeless is four times higher than the proportion of the French population.

The survey results at the national level also revealed highly unstable figures on the homeless population. Depending on the capacity of the facilities available, the number of people 
Table 8: Important attributes of the homeless population

\begin{tabular}{|c|c|c|c|}
\hline \multirow{2}{*}{ Attributes } & \multicolumn{3}{|c|}{ Homeless people using aid services (\%) } \\
\hline & All & Male & Female \\
\hline \multicolumn{4}{|l|}{ Income per consumption unit* } \\
\hline First decile & 74 & 76 & 72 \\
\hline Second decile & 13 & 11 & 15 \\
\hline Third to tenth deciles & 10 & 10 & 10 \\
\hline \multicolumn{4}{|l|}{ Socio-professional group } \\
\hline Farmers, tradesmen and employers & 5 & 6 & 4 \\
\hline Middle-managers, intellectual professions & 3 & 3 & 2 \\
\hline Intermediary professionals & 8 & 9 & 7 \\
\hline Employees & 33 & 19 & 56 \\
\hline Manual workers & 41 & 57 & 12 \\
\hline Unemployed who have never worked & 4 & 2 & 8 \\
\hline Other economically inactive people with no profession & 7 & 4 & 11 \\
\hline \multicolumn{4}{|l|}{ Current occupation } \\
\hline Self-employed & 1 & 2 & 0 \\
\hline In an open-ended contract or other contract with no time limit & 7 & 6 & 10 \\
\hline In a fixed-term contract & 4 & 4 & 5 \\
\hline $\begin{array}{l}\text { Other short-term contract (employment solidarity contract (CES), temporary employment, intern- } \\
\text { ship) }\end{array}$ & 16 & 19 & 10 \\
\hline Unemployed for more than a year & 21 & 22 & 19 \\
\hline Unemployed for less than a year & 20 & 19 & 22 \\
\hline Economically inactive & 30 & 29 & 33 \\
\hline \multicolumn{4}{|l|}{ Qualification } \\
\hline No qualifications & 46 & 46 & 46 \\
\hline Primary studies certificate, BEPC (first cycle diploma), Elementary diploma, schools diploma & 18 & 15 & 23 \\
\hline CAP (Certificate of vocational proficiency), BEP (Vocational training diploma) & 10 & 23 & 13 \\
\hline General, technological, or vocational baccalaureat, technical diploma & 10 & 9 & 12 \\
\hline Higher education qualification & 7 & 8 & 6 \\
\hline \multicolumn{4}{|l|}{ Age } \\
\hline 18 to 24 years & 25 & 26 & 28 \\
\hline 25 to 34 years & 30 & 27 & 35 \\
\hline 35 to 44 years & 25 & 25 & 25 \\
\hline 45 to 54 years & 18 & 23 & 10 \\
\hline 55 to 64 years & 7 & 10 & 2 \\
\hline \multicolumn{4}{|l|}{ Country of birth } \\
\hline Born in France or an EU member state (EU15) & 69 & 70 & 67 \\
\hline Born in a European country outside the EU (EU15) & 3 & 3 & 4 \\
\hline Born in Algeria, Morocco or Tunisia & 16 & 17 & 13 \\
\hline Born in anther African country & 12 & 10 & 16 \\
\hline \multicolumn{4}{|l|}{ Length of time spent in Metropolitan France } \\
\hline Not applicable, born in France & 66 & 67 & 63 \\
\hline Less than a year & 9 & 10 & 7 \\
\hline Between 1 and 5 years & 8 & 6 & 11 \\
\hline 5 years or more & 17 & 17 & 18 \\
\hline \multicolumn{4}{|l|}{ Father's socio-professional group } \\
\hline Manual worker, employee & 67 & 66 & 68 \\
\hline Middle-manager, professional, craftsman, tradesman, farmer & 33 & 34 & 32 \\
\hline
\end{tabular}


Table 8: (continued)

\begin{tabular}{|c|c|c|c|}
\hline \multirow{2}{*}{ Attributes } & \multicolumn{3}{|c|}{ Homeless people using aid services (\%) } \\
\hline & All & Male & Female \\
\hline \multicolumn{4}{|l|}{ Childhood poverty* } \\
\hline Economic difficulties before the age of 18 & 34 & 32 & 38 \\
\hline No economic difficulties before the age of 18 & 66 & 68 & 62 \\
\hline \multicolumn{4}{|l|}{ Illness or death of one parent* } \\
\hline Illness or death before the age of 18 & 48 & 51 & 53 \\
\hline No illness or death before the age of 18 & 52 & 63 & 51 \\
\hline \multicolumn{4}{|l|}{ Divorce of or dispute between parents* } \\
\hline Divorce or dispute before the age of 18 & 41 & 37 & 49 \\
\hline No divorce or dispute before the age of 18 & 59 & 63 & 51 \\
\hline \multicolumn{4}{|l|}{ Declared state of health* } \\
\hline Good & 17 & 19 & 14 \\
\hline Average & 36 & 35 & 37 \\
\hline Bad & 47 & 46 & 49 \\
\hline
\end{tabular}

Note: * The variables come from the Santé survey.

Source: Brousse (2009).

that actually dwell on the street continually varies. Four types of facilities are mainly available: emergency centres to provide night shelter, shelter and reintegration centres that are open during the day, centres where the length of accommodation can vary from two to six months and dwellings and hotel rooms owned by shelter providers (NGOs, government etc.). Among the homeless, around 23\% may be at the bottom in the sense that they either live in makeshift shelters or stay at an emergency centre during the night (Join-Lambert, 2009). In the qualitative fieldwork it was observed that people gather in certain specific places, such as metro stations, around 11:00 $\mathrm{pm}$, from which the night shelter providers and sometimes also the police pick them up. Sometimes they manage to sleep inside the metro stations, where group behaviour is important as a safeguard against the administration not allowing them to remain and also to give them courage. Those that resist staying in emergency centres due to overcrowding find metro stations much safer and, if they find it difficult to enter the metro station, then the second-best option is to sleep at restaurant, cafeteria and department-store premises. Homeless people spending only the night in shelters is an old institution in France. Other than unwillingness to stay in a shelter, supply constraints also need to be mentioned. Many do not manage to get in during the night because the centres are filled to capacity. The centres are usually occupied by foreigners waiting for residence permits and older men.

Contrary to the popular belief that the homeless population is idle and mainly depends on charity, around one-third have jobs as manual or unskilled workers (Debras et al., 2004). In addition, most of them have contacts of some form or another with relatives and friends or social institutions. In fact, Cécile
Brousse (2009) highlights the highly heterogeneous nature of the homeless population in terms of family configuration and labour-market relationship: single professionally inactive people (45\%), who are mostly males; a younger, better-qualified category, who are living neither with a partner nor children but are working (22\%); women mostly with children (18\%); relatively young people living with partners and/or children (13\%); and older people over 50 (2\%). In terms of income, there is wide variation among the homeless. In comparison to other poorly housed people with low incomes, the percentage of the population with very low incomes and the percentage of people with relatively high incomes among the homeless are higher. Marpsat (2009) compared individuals with no independent housing with those that have independent housing but are dependent on services such as hot-meal distribution. She noted that those with independent housing had extensive job experience but were mostly jobless at the time of survey due to ill health or age. However, the percentage of individuals without jobs was higher among those with housing but dependent on food distribution in comparison to those that had no independent housing at the time of the survey. Other than the fact that people in this kind of housing had longer job careers in the past, benefits such as adult disability allowances, retirement pensions or minimum old-age pensions from the state, and housing benefits would explain why they were able to access housing though they were as vulnerable as those without independent housing. Marpsat (2009) also noted that many of the individuals that had housing but depended on the services meant for the homeless population had once been homeless, indicating the gross inadequacy of rehabilitation measures. Because many of these individuals with independent housing are older, this calls for a more integrative approach to the 
problem of homelessness so that the rehabilitation measures can yield better results. Firdion (2009) emphasises that among the homeless those that have a job have higher levels of education, social capital (contacts with parents, family and friends) and also health capital (i.e., they are younger and healthy). In fact, in the case of females social capital also determines access to social assistance.

Conditions in the labour and housing markets, inadequate public policy measures to help people in difficulty and insufficient care facilities for the mentally ill are some of the structural causes of the spread of homelessness, although homeless people might not be able to identify the actual cause and hence may not have cited the immediate cause as the reason for their homelessness (Marpsat, 2000). Among females, the proximate cause of homelessness was "relationship breakdown" and among males it was job loss and periods spent in hospitals and prisons. Many homeless come from northern France and they are often engaged in odd or irregular jobs. Among young people, some of the common causes of homelessness are social background such as foreign nationality, parents working in agriculture, family breakdowns due to conflicts between parents and children during the transition to adulthood, and being victims of discrimination.

Brousse (2009) points out that nearly three-quarters of the homeless population using aid services belong to the working class and half of them have no job skills. Almost $60 \%$ of homeless middle managers are foreign nationals, although this category accounts for only $3 \%$ of the total homeless population. The migration factor and illegal status seem to be related to homelessness, although the magnitude is not alarming. As Table 8 shows, a large percentage of males that worked as manual labourers have become homeless. Among women, on the other hand, the broad category of "employees" comprises around $56 \%$ of those that are currently homeless.

Almost $40 \%$ of the homeless have been unemployed and $30 \%$ are economically inactive, which implies that joblessness and homelessness have a strong connection because the economically inactive category might have resulted from what are known as "discouraged dropouts" from the labour market (Table 8). ${ }^{[3]}$ In addition, many of those that have been working are mostly employed on short-term contracts, at a rate almost five times higher than that in the rest of the population. All of this adds up to the fact that around $80 \%$ of the homeless population using aid services fall into the bottom income class. The response of the homeless population to why they became homeless is as follows: marital break-up and home loss (26\%), no longer living with parents (21\%), migration (19\%), lack of housing for financial reasons (unable to pay rent etc., 16\%), demolition of the house or the end of the lease (3\%), leav- ing institutions such as hostels, hospitals and prisons (12\%) or looking for a job or large family size (3\%). These reasons are not mutually exclusive, but there is a broad pattern across gender or age groups. Among homeless men, evictions, leaving an institution and migration are the most important factors; leaving the parental home includes mostly young men, and marital break-up is important among both middle-aged men and women.

It is important to note that many homeless individuals belong to relatively young age cohorts. More than half of the homeless are in the 18 to 25 age group and nearly half of the population have been in bad health. More than $60 \%$ did not suffer from childhood poverty. Similarly, an equal percentage did not indicate that one of their parents had died young or that they had experienced a family dispute. All of this tends to suggest the phenomenon of downward social mobility resulting from labour-market strains. Inadequate human capital alone cannot be held responsible for this because only half of the population said that they had no education. There seem to be demand-side constraints as well.

More than $65 \%$ of the homeless were born within France itself. Therefore it is not justified to explain the situation purely in terms of migration, illegal status and lack of institutional support. In other words, although a poor economic background in terms of parental occupation, poor human capital formation and migration from other countries does have a connection with homelessness, it is also possible to go beyond this framework and identify the labour-market hardships that essentially reduce the capability to access decent housing.

An international review of homelessness and social housing policy suggests a link between weak welfare states, low levels of affordable housing and high levels of homelessness (Communities \& Local Government, 2007). The role that rent control plays in addressing homelessness is influenced by the rules governing access and prioritisation, as well as the sector's overall size. Although it produces relatively good housing outcomes for low-income households, it comes at the cost of spatial concentration because rent-controlled housing is geographically concentrated. However, with high levels of inequality and poverty it is difficult to implement these programmes for all the beneficiaries.

\section{Conclusion}

This paper analysed the issue of homelessness in France, keeping in view three major mutually interacting sets of factors: labour-market strains and the lack of social capital, illegal migration and institutional inadequacy. Against the backdrop of labour-market hardships, the paper explores possible intercon- 
nections between joblessness and homelessness. In this connection, the available evidence tends to lend support to the hypotheses stated at the beginning of this paper. The findings are indicative of a strong effect of homelessness, poor human capital formation and inadequate housing at affordable prices accompanied by insufficient institutional support and accentuated by the problem of illegal migration. The macroeconomic challenges resulting in loss of jobs and the subsequent labour-market hardships tend to affect those with fewer skills. Moreover, labour-market obstacles combined with inadequate social capital reduce access to decent housing, the prices of which have been skyrocketing with increased economic activity and growing inequality of access to housing within the city. The rise in the employment rate does not necessarily indicate a potential improvement in accessing housing because the negotiations for expansion in employment in the face of persistent unemployment had to be initiated at the expense of wage growth. In such a situation, the inadequacy of institutional support and the failure of the state and civil society to improve low-cost shelter for the economically weaker sections of society have aggravated the problem of homelessness. On the other hand, several rigidities in the system are also responsible for increasing the incidence of poor-quality living; these include the inability of vocational and training institutes to adjust to new changes and requirements, the inflexibility of capital-intensive technology to create space for labour in a time of crisis and the outsourcing process, which is reducing relatively less-skilled jobs in developed countries due to wage differentials across the developed and developing world.

Notwithstanding these changes, there are certain endemic issues relating to homelessness: for example, even if a sufficiently large number of jobs in the construction sector were created for less-skilled workers, beyond a certain age individuals simply may not have the ability to pursue work in order to have access to rented accommodation and avoid homelessness. On the other hand, savings from past income may not be sufficient to acquire land or housing. All of this argues for active intervention by the government in the housing market in order to create space for the relatively weaker section of the population. The issue of illegal status is important because illegal migrants are not allowed to work. Hence, their vulnerability tends to become aggravated because they accept marginal and menial jobs merely to survive.

In addition, an important issue is how to create jobs with positive growth in real wages because without adequate purchasing power simply providing housing would mean the transfer of poverty from one space to another. In this respect, the issues of skill formation, on-the-job training and provision of opportunities to enhance human capital are some important strategies for improving productivity and reducing job-market vulner- abilities, which in turn may curb housing poverty in France. Regarding social capital, daytime centres or community centres can play an effective role in cultivating new contacts, which in turn can be effective in providing a boost to the social morale of the homeless population. Networks among them will not only strengthen their social standing, but also help create new institutions for better negotiation with the state. Greater initiative on the part of the sufferers themselves can certainly be more fruitful in making growth less exclusionary. Because the social cost of providing for those on the lowest rungs of the social ladder is much higher in developed countries compared to developing countries, strategies to involve the poor in overcoming the constraints on their wellbeing appear to be a more pragmatic approach.

\section{Arup Mitra}

Sciences Po (Institut d'Études Politiques de Paris), Paris, France Institute of Economic Growth, Delhi, India

E-mail: arup@iegindia.org

\section{Notes}

[1] Women are less homeless due to safety nets and people of African origin have many NGOs working for them. Middle-aged French in low-skilled jobs are rather more vulnerable and likely to become homeless

${ }^{[2]}$ However, the authors had difficulty considering the homeless population as a distinct social category because they shared a social proximity with other people living in conditions of poverty and economic insecurity, although not homeless.

${ }^{[3]}$ However, employment is sometimes unreported because illegal migrants are not allowed to work (Marpsat \& Firdion, 2001).

\section{Acknowledgement}

The author is grateful to Maryse Marpsat and Jean-Marie Firdion for their help, suggestions and reference materials. This paper draws heavily from several of their past studies. Veronique Dupont extended generous support and provided effective direction for this research. Alessia Lefebure, Director of the Asia Pacific Centre, Sciences Po, Paris helped with the overall logistics. Thanks to Regine Serra for encouraging research in this area. Finally, the support staff at the centre, Marie Valincolin and Catherine Capelle-Benchimol, were extremely helpful and cooperative. The author is grateful to all of them and the usual disclaimers apply.

\section{References}

Arbonville, D. (2000) Normalisation de l'habitat et accès au logement entre 1984 et 1992. Une étude du "parc social de fait". In: Marpsat, M. \& Firdion, J. M. (eds.) La rue et le foyer. Une recherche sur les sans-domicile et les mal-logés dans les années 90, pp. 31-62. Paris, PUF/INED.

Avramov, D. (1995) Homelessness in the European Union. Social and 
legal context of housing exclusion in the 1990s, Brussels, FEANTSA.

Brousse, C. (2009) The homeless support network: A segmented world. Available at: http://www.insee.fr/fr/publications-et-services/ docs_doc_travail/Docf0906.pdf (accessed 1 Mar. 2011).

Crepon, B. \& Dezplatz, R. (2001) Une nouvelle évaluation des effets des allégements de charges sociales sur les bas salaries. Économie et statistique, 348, pp. 3-24. DOI: 10.3406/estat.2001.7420

Communities \& Local Government (2007) An international review of homelessness and social housing policy. Research report. Wetherby.

Debras, B., Chamboredon, H. \& Thiery, P. (2004) Dans

l'agglomération parisienne, un sans-domicile sur trios déclare avoir un employ. île de France à la page, 241, pp. 1-3.

Decressin, J., Estevao, M., Gerson P. \& Klingen, C. (2001) Job-rich growth in Europe. Country report. Washington, International Monetary Found.

Estevao, M. \& Nargis, N. (2005) Structural labour market changes in France. Available at: http://ftp://repec.iza.org/RePEc/ Discussionpaper/dp1621.pdf (accessed 1 Mar. 2011).

Firdion, J. M. (2009) Influence of early-life events and the legacy of social background among users of services for the homeless. Available at: http://www.insee.fr/fr/publications-et-services/docs_doc_travail/ Docf0906.pdf (accessed 1 Mar. 2011).

Firdion, J. M. \& Marpsat, M. (2007) A research programme on homelessness in France. Journal of Social Issues, 63(3), pp. 567-587. DOI: $10.1111 / j .1540-4560.2007 .00524 . x$

Garibaldi, P. \& Wasmer, E. (2002) A survey of the literature on labour market flows between activity and inactivity. Available at: http://www.cepr.org/RESEARCH/Networks/LESER/LESER_survey.pdf (accessed 1 Mar. 2011).

International Labour Organisation (2009) Key indicators of the labour market, 6th edition. Geneva.

Join-Lambert, M. T. (2009) A special survey. The homeless: a new survey. Économie et Statistique. Special issue on the homeless, English version, pp. 3-15. Available at: http://www.insee.fr/fr/publicationset-services/docs_doc travail/Docf0906.pdf (accessed 1 Mar. 2011).

Marpsat, M. (2000) An advantage with limits: The lower risk for women of becoming homeless. Population: An English Selection, 12, pp. 247-292.

Marpsat, M. (2005) Beyond literal homelessness. Paper presented at the 5th CUHP Workshop, April 21-22, Milan, Italy. Typescript.

Marpsat, M. (2009) A discreet form of poverty: housed persons using hot meal distributions. Available at: http://www.insee.fr/fr/ publications-et-services/docs_doc_travail/Docf0906.pdf (accessed 1 Mar. 2011)

Marpsat, M. \& Firdion J. M. (1996) Becoming homeless: Who is at risk? Population et Sociétés, 313, pp. 1-4.

Marpsat, M., Firdion, J. M. \& Meron, M. (2000) The difficult past of young homeless people. Population et Sociétés, 363, pp. 1-4.

Marpsat, M. \& Firdion, J. M. (2001) Les ressources des jeunes sans domicile et en situation précaire. Recherches et prévisions, 65, pp. 91-112.

Meijers, F. (1998) The identification of relevant labour market information for vocational education and training: A user oriented approach. In: European Training Foundation (ed.) Skill needs: Linking labour market analysis and vocational training. Report, pp. 74-83. Luxembourg, European Communities.

Philippot, P., Lecocq, C., Sempoux, F., Nachtergael, H. \& Galand, B. (2007) Psychological research on homelessness in Western Europe: A review from 1970 to 2001. Journal of Social Issues, 63(3), pp. 483-504. DOI: 10.1111/j.1540-4560.2007.00520.x

Pisani-Ferry, J. (2000) Plein emploi. Paris, Conseil d'Analyse Économique.

Riding, A. (1993) Paris journal; France's homeless get help! Read all about it! New York Times, 10 Nov. 1993.

Toro, P. A., Tompsett, C. J., Lombardo, S., Philippot, P., Nachtergael, H., Galand, B. et al. (2007) Homelessness in Europe and the United States: A comparison of prevalence and public opinion. Journal of Social Issues, 63(3), pp. 505-524. DOI: 10.1111/j.1540$4560.2007 .00521 . x$

Vazquez, C., Munoz, M., Crespo, M., Guisado, A. B. \& Dennis, M. (2005) A comparative study of the twelve-month prevalence of physical diseases among homeless people in Madrid and Washington, DC. International Journal of Mental Health, 34(3), pp. 35-56.

Wheaton B. (1985) Models for the stress-buffering functions of coping resources. Journal of Health and Social Behaviour, 26(4), pp. 352-364. DOI: 10.2307/2136658. 